\title{
Animal Vision and Life Consciousness-'Horse' in D. H. Lawrence's 1920s Short Stories
}

\author{
Xinzhe You ${ }^{1}$ \\ ${ }^{1}$ School of English Studies, Shanghai International Studies University, Shanghai, China \\ Correspondence: Xinzhe You, School of English Studies, Shanghai International Studies University, 1550 \\ Wenxiang Road, Songjiang District, Shanghai, China. E-mail: 0193100160@shisu.edu.cn
}

\author{
Received: April 20, 2021 Accepted: May 25, $2021 \quad$ Online Published: May 30, 2021 \\ doi:10.5539/ells.v11n2p78 URL: https://doi.org/10.5539/ells.v11n2p78
}

\begin{abstract}
D. H. Lawrence is seeking for the consciousness of life throughout his lifelong creation; he resorts to animals that bear closer connections with nature mainly in the 1920s. Based on three short stories which mention 'horse' in the title, "The Horse-dealer's daughter" (1922), "The Woman Who Rode Away" (1925) and "The Rocking-horse Winner" (1926), this essay illustrates how horses function as Lawrence's pastoral ideal, pursuit for the primitive and shape of humanity. From the background that represents the past agricultural lifestyle to a life vehicle that carries the woman to freedom, and finally to a symbol with fantasy that mirrors crises in human relations, Lawrence's deepening attention towards the 'horse' belabors his life pursuit of the primitive and balances between the binary oppositions of animality and humanity, finding for modern people a way out of distortions under industrialization and civilization.
\end{abstract}

Keywords: horse, animality, life, short stories, D. H. Lawrence

\section{Introduction}

He [Horse] is a dominant symbol: he gives us lordship: he links us, the first palpable and throbbing link with the ruddy-glowing Almighty of potence: he is the beginning even of our godhead in the flesh. And as a symbol he roams the dark underworld meadows of the soul (Lawrence, Apocalypse, p. 97).

D. H. Lawrence is never to be buried in obscurity in the literary scene as a genius and prolific novelist, poet, reviewer, thinker, literary critic and even a painter, almost all of whose masterpieces elaborate on the inroads that the over-speed industrial developments have made into human society. Although misunderstood by some owing to his unconventional touches upon sex and irrationality (Note 1), Lawrence's contributions to modernism take some beating - emphasizing the importance of animality in shaping humanity, thus offering a way of balance in this distorted modern world under industrialization and commercialization.

It is the major theme of the beginning of the twentieth century to break with the tradition and limitations of an industrialized society under rapid pace of science and technology. Some major modernist literary figures have taken this rebellious spirits into practice: the Imagists, represented by Ezra Pound, directed their foci to the "thing" itself, refining the rhetoric of language and conventions of rhyme to emphasize the exact mood instead of pastoral sentiments on social issues; E. M. Foster concentrated on personal relationships amid the complexities of English gentility, searching for "a world of vital exuberance" out of the British middle-class values (Reidhead, 2018, p. 248); Virginia Woolf delved into moments of importance of human consciousness, creating literary works that are "androgynous in mind" for the awakening of female power; James Joyce, soaked in Dublin, pounced upon the state of exile and flagged up the paralyzed modern society... It is D. H. Lawrence who, with animals being the protagonists rather than the environmental background in his works, came forward among his contemporaries in depicting nature-humans' deepest connection with the world, and attached great importance to non-human animals so as to find a balance for the distorted human society.

Lawrence woke up to animals as the most significant portion of the living universe and particularly in the 1920s, he shifted his focus from men and women relationship to men and animal connections. Regarded as a trail-blazing pioneer of human-animal relationship, he resorted to animals as the access to the primitive, matching up with his philosophy of "blood-consciousness"- to seek the "down to the earth" power (Lawrence, 2004 , p. 114). The mining culture where Lawrence grew up and the tuberculosis that he suffered from left 
Lawrence only the sense of doom and gloom to the highly industrialized land. Lawrence's consuming passion for the living universe originated from the primitive animism presented in Primitive Culture by Edward Tylor who believed the biological phenomena of "Life and Death, Health and Disease, Sleep and Dreams, Trance and Visions" formed into the plurality of souls that lead up to Life (Tylor, 1871, p. 10). Lawrence's great emphases on animals in his works during the 1920s are worth mentioning, both in fiction and non-fiction treatises or poem collections as represented by Birds, Beasts and Flowers (1923), Kangaroo (1923), St Mawr and Other Stories (1925), The Woman who Rode Away and Other Stories (1928) and so forth. With the release of Psychoanalysis and the Unconscious (1921) and Fantasia of the Unconscious (1922), Lawrence's animal turn in the prime of his creation is inferred from his attention of humans' connection with animals, "The primal consciousness in man is pre-mental, and has nothing to do with cognition. It is the same as in the animals" (Lawrence, 2004, p. 79). Such a pre-mental stage is lost during the rapid development of industrialization.

So far, most critical analyses on Lawrence's animals find a foothold in his ecological collection Birds, Beasts and Flowers (1923) which contains animal poems that best represent Lawrence's preoccupation with Nature. R. P. Draper collected a review on this collection in Times Literary Supplement that generally summarized Lawrence's insights into the human society based on the vision of animals and plants in nature. ${ }^{2}$ David Ellis further focused on "voice" of nature that differentiated Lawrence's writings with T. S. Eliot's, delving into Lawrence's attention to animal depiction due to his "powerful poetic presentation of 'otherness"." (2003, p. 395) Animals in novels, however, bear closer attachments to humans and are featured as oppositions of humanism, thus emphasizing more the inseparable tie between humans and non-human others, compared with those in poetry.

If the 1920s is noted as Lawrence's turn to animals, then it is one particular kind of animal that wins Lawrence's constant attention - horses. The images of horses run through most of his well-known works. The stallion in Sons and Lovers (1913) as a catalyst to the decline of Paul and Miriam's spiritual love and stimulus of Paul and Clara's physical love; the horse in "The Prussian Officer" (1913) as a symbolic of the captain's rank; the group of horses in The Rainbow (1915) as the deciding key to Ursula's death and rebirth. Literary interpretations of horses mostly lie in symbolization of horse-related discourses, horsemanship and status as well as horse-human identities. As domesticated animals, horses have long been considered as labor forces, fulfilling humans' routine businesses of riding, breeding, selling, driving and handling. Unlike the asses, horses are among the 'nobility' in pre-industrial domesticated animals. Peter Edwards and Elspeth Graham view horses as cultural icons, attaching horses to sex and power (Note 2). Amanda Eisemann emphasizes horses' link to masculinity by exploring horses' bodies as "territories for men...[their] identities supported certain social assumptions about gender and class" (2012, p. 380). In addition to slavishly domestic labels and unattainably wild spirits, horses are ascribed a prehistoric and mythical aura by Lawrence.

Horses suggest the developing process of Lawrence's animal view. Even though the three short stories which contain 'horse' in the title in Lawrence's 1920s, "The Horse-dealer's daughter" (1922), "The Woman Who Rode Away" (1925) and "The Rocking-horse Winner" (1926) are widely discussed, not many have studied the function of horses. Shirley Bricout linked the "tied up draught-horses [that] lack such vitality" with the reification of humans in the analyses of "The Horse-dealer's daughter," holding the horse dealings to arouse a pastoral nostalgia. (2017, p. 67) Ria Banerjee, in his critical essay on "The Woman Who Rode Away," regarded the horse that "plodded dejectedly on" as a sway of the woman's mind, "...And if she had any will of her own left, she would have turned back..." (2012, p. 79) W. R. Martin formed a contrast between the lively and real horses and the wooden horse in "The Rocking-horse Winner": "The rocking-horse is seven times referred to simply as the "horse'," blaming ironically on the mechanization of human life. (1962, p. 65) Several critics have concentrated on the inner developing ideas through Lawrence's 1920s short stories. Kathryn Miles, for example, woke up to Lawrence's progressive notion of human-nature relationship based on the narrative techniques in "The Horse-dealer's daughter" as well as "The Rocking-horse Winner." So far, few has pointed out 'horse' as a key element that connects the three short stories. This essay, by analyzing horses that reflect 'the rural,' 'the primitive' and 'the fantastic,' explores Lawrence's deepening attention towards horses in the 1920s and the pursuit for a "living universe."

Whatever symbolic meanings horses bear, the fantastic elements in Lawrence's short stories make possible the coexistence of three pairs of conflictive powers triggered by horse-related discourses: industrialization and agricultural tradition; civilization and the primitive; animality and humanity. It is the 'free' style of literary fantasies according to Rosemary Jackson, “... [literary fantasies] doing away with chronology, three-dimensionality and with rigid distinctions between animate and inanimate objects, self and other, life and death" $(2009$, p. 1) that adds a sense of "grotesque" to the content and form. From horses as appearing in the 
background of the story to the setting of horse as an essential symbol that promotes the plot, D. H. Lawrence's increasing preoccupation with the image of horses serves as what Bakhtin believed the fantastic can achieve: "not for the positive embodiment of the truth, but as a mode for searching after the truth, provoking it and, most important, testing it" (1984, p. 114).

\section{Horse the Rural: Awakening of Animal Instincts in "The Horse-Dealer's Daughter"}

Horses symbolize Lawrence's pastoral ideal. Peace was broken when the last horse business by the Pervins was to be done with "confused tramping of horses' feet" outside. The stagnation of horse industry led to the bankruptcy of a family who used to make a living on this agricultural civilization. Ever since the rise of capitalism in Britain, lands had been enclosed, fenced and becoming private possessions rather than being used collectively before the enclosure movement, during which all the treatments of domesticated animals such as cattle, sheep, horses, asses, hens, pigs etc. were in the aim of gaining as many profits as possible. Up till the late 19th century when machines took the place of conventional husbandry, a major victim of traditional agriculture's transforming into an industrial one was domesticated animals who were mainly utilized as the labor forces on farms. Horses, oxen and asses were mostly used as animal-powered engines such as the oblique (Note 3). A common scene of London's streets then was depicted by John Gay in Trivia (1716), "Wheels clash with Wheels" and "The lashing Whip resounds, the Horses strain, /And Blood in Anguish bursts the swelling Vein" (qtd. in Perkins, 2007, p. 14). The stables of the Pervins, however, which used to be in a turmoil with "come-and-go of horses and of dealers and grooms" are now empty (Lawrence, 2012, p. 314). The increasingly modernized society no longer requires horses as domesticated labors, leading up to the collapse of agricultural industries represented by the horse dealings.

To a deeper extent, the domesticated-ness of horses is paralleled to the passivity of humans' attitudes towards life. The four heavy-loaded horses, "tied head to tail," moving forward in the groom's leading rope, symbolized Mabel's four siblings, who, though suffering from the misery of bankruptcy, engaged themselves endlessly in material pursuits. "The horses were almost like his [Joe's] own body..." Joe's hopeless gaze at the draught-horses, Fred's "sang-froid" as the master of horse but not that of life, Malcolm's horsey fashion suggested a sense of stupidity that Lawrence attached to modern people, just as the sufferings of the domesticated horse subjected to labor work for human beings (Lawrence, 2012, p. 305).

As victims of industrialization, the inert horses, "in a motion-like sleep," reminded Mabel of the repressed life, ineffectual communication and selfish behaviors of the family members, preparing for the rebirth of her sensuality. Instead of traditional narrative devices as plot and characterization, Lawrence digs deep into the interiority, the "subtleties of interpersonal dynamics" (Miles, 2008, p. 184). By depicting the overturn of Mabel and Ferguson's physical attachment to their conventional moral bounds, Lawrence reforms human sensibilities, calling for one's animal instincts hidden in humanity. Mabel's bodily attachment with Ferguson broke free of their stubborn doctor-patient relationship, though he had no intention of loving her at first glance. Lawrence insists a basic distinction between one's conscious mind and the unconscious, the latter of which being his 'blood' philosophy, “....we can go wrong in our minds. But what our blood feels and believes and says, is always true" (Lawrence, 2004, p. 21). Despite others' groundless gossips about their relation, Ferguson's "I love you! I love you!" dispelled all the previous concerns, thus proving how inner emotions win over rationality (Lawrence, 2012, p. 335).

The pond fantasy where both the doctor and Mabel plunge into the pond and finally remain alive saw mutual rejuvenation of the two. The liminal state, neither alive nor dead, they faced in the pond prepared for the power of rebirth. Ferguson saved Mabel from the pond, awakening her remaining 'liveliness' - the animal instincts that weaved a magic to Mabel's 'rebirth.' But it was the innermost body of life in Mabel that attracted Ferguson, a man who could not swim, to venture into the pond without any hesitation. In this sense, Mabel was searching for a new way of living more than committing suicide in the pond. Ferguson's miraculous rescue helped the completion of Mabel's life. Then, their physical affection fed back on Ferguson's human instincts, thus highlighting the transfer from their physical emancipation to spiritual and psychological communication.

\section{Horse the Primitive: Envoy of Peace in "The Woman Who Rode Away"}

By the end of "The Horse-dealer's Daughter," Ferguson's seemingly affirmative but hasty promise with the terrible intonation "No, I want you, I want you..." left a spate of uncertainties: Is this a carefully considered decision? Will Ferguson go back on what he has promised? Can Mabel really get rid of her previous repressed life in her marriage with Ferguson? Lawrence himself is not sure; he is exploring the unconscious power that exists deeply in the blood, and the animal instincts that take human beings away from distortions. This massive and slumberous strength can be found in the horse. 
The frequent occurrence of horses in Lawrence's writings reflect his cling to animality, which is based on a call for the primitive: attentiveness to animals that "our faraway ancestors possessed and we have lost" (Coetzee, 2003 , p. 97). He stripped horses of the role as submissive domesticated animals in "The Woman Who Rode Away," and instead, imbued prehistorical features of the horses in which they are "swift and fierce and supreme, undominated and unsurpassed" (Lawrence, 1925, p. 26). Just as what he has pointed out in his Fantasia of the Unconscious that a horse's gaze, "bright and glancing...full of terror...aggressive and frightening," is different from a cow's gaze (p. 201). Horses as "savages" echo Lawrence's call for a return to the primitive and search for animality. If the slumping horse dealings ring down the curtain of the traditional agricultural-centered life style, and flags up men and women relationship, then the horse on which the female protagonist rides further calls attention to femininity and humans' interrelations to nature, forwardly playing the role as a bridge to spiritual freedom and intercultural peace.

The horse on which the woman rides takes her away from her husband, the previous religious belief like an albatross around her neck, as well as the social duties of women that weigh heavily on her. Interested in the "funny sort of hats with flowers [a]round" and the almost naked people with a sort of shirt, "striding round with their savage's bare legs," the woman headed for the fanciful old religions and mysteries with a vague enthusiasm and curious imagination for unknown Indians - "it must be wonderful, surely it must" (Lawrence, 1928, p. 13). The horse almost disappeared where the story was shifted from reality to fantasy. The primitive fantasy featured the major conflicted clues of the story: the woman headed for the primitive villages by herself, someplace she might not have heard before. Nevertheless, she was also afraid of the spark in the Indians' eyes like what could be seen in a snake's eyes, "paralyzed with fear" of the Indian rituals, feeling as if she is dying, "She knew she was dead" (pp. 32, 24). A potential power can be felt under the physical body of the horse.

That the symbolization of the horse as an envoy of freedom and annihilation of the dominated White consciousness also meets some limitations. The horse indeed resembles independence of the woman to get rid of domestic slavery, a heroic femininity to break loose from her husband's dominance, but can the woman fully represent white womanhood? If so, her decisive submission to the Indian religion seems unreasonable. With no name from the beginning to the end, the woman is just an archetypal scapegoat who has no choice but to pay for the sins of the White race in hiding human passions and depriving liveliness of life.

However, the woman can be seen as an envoy of peace who succeeds in arousing the natural bonds between the White people and the Indian aborigines. Different from the White people who are immersed in a more cultured society represented by delicate clothes, sophisticated social classifications, beautiful toys, the Indians bear closer relationship with nature; they live their lives with the natural shifts of the sun and the moon,

...our men are the fire and the daytime, and our women are the spaces between the stars at night...the man all the time have to keep the sun happy in his side of the sky, and the woman have to keep the moon quiet at her side of the sky (Lawrence, 1928, p. 63).

Immersion in nature differs the Indian aborigines who live in a primitive state of life from the White people mired in spiritual decadence. It is the mystical power contained in nature that nourishes all living creatures. There being no specific God as Christianity requests, every living thing in the world can be God Pan with a freedom of the spirit. The woman was no longer a female in the Indians' eyes, but a sacrifice "perfumed with incense and sprinkled with ash" to regain peace from the sun and the moon which were shut by the white people (p. 56). Thus, the blue wind, incarnation of the white woman, was sent to the sun and the moon so as to open the gate that had been shut by civilization of the white consciousness. The color blue implied by the blue eyes of the woman also marked the "colour of dead" (p. 58). In this sense, the Indians' intention of bringing a red horse to a blue mare indicates the arouse of the primitive connection with nature covered up by human civilization.

The horse that takes the woman away marks Lawrence's shifting foci on horses as domesticated animals of the past to a savage whose primitive power is what modern society lack. The process of the woman's escape was faced with a spate of disagreeables, during which the horse was pulled, struck and reined fiercely. Being no longer the background that represents nature and labor force, the horse features a life-symbol that feels and resists. Be the woman an envoy of peace and freedom, or rather a victim and sacrifice of Western civilization, she succeeds in escaping from her husband, a typical symbol of white consciousness. To Lawrence, killing seems to be as natural as "lying with a woman" (Lawrence, 1923, p. 376). The ritualized murder of the young protagonist, thus, is no tragedy: the woman is faced with her bodily death, but experiences a rather vivid life, the spiritual freedom nowhere to be gained in her past.

\section{Horse the Fantastic: Mirror of Humanity in "The Rocking-horse Winner"}

The rocking-horse is the externalization of the young protagonist's Oedipus complex (Note 4), on which Paul 
rides to predict the token of the victory horse. The wooden horse bears more function than mere winner prophesy; it drives Paul to his mother's heart, bearing Paul's deep wish of close attachment to his mother. Such distorted maternal love results from the grasping materialism and advancements in industrial regions, leading up to the turbulent society lacking in spiritual life. This connection of one's psychological interrelations to animals can be traced back to Freud who resorted a five-year-old boy Hans' fear of his father to the phobia of a horse, regarding the father to be a competitor for the favors of the mother, towards whom "the obscure foreshadowing of his budding sexual wishes were aimed" (Freud, 2001, p. 149). The child's displacement of his feelings from the father to the horse suggested not only the child's detest of the father, but the appreciation of his mother. Thus, an original totemism, an inner power of the horse that attracted the child, can be inferred, for as long as the boy conquered his fear, he could approach the horses with interest and admiration.

The superpower of the rocking-horse discloses fantasy in the family relation, calling for one's suppressed sensual self. Lawrence considers "the horse as an image of fear [that] refers to the great sensual centre, subjected to domestic control, but flashing terribly into anger and hostility" (2004, p. 287). Instead of being a son, Paul played the role of a father in the family. The ever-lasting whisper: "There must be more money! There must be more money!" deprived the young boy of a carefree childhood, forming the materialistic background of the story (Lawrence, 1994, p. 551). Such an urgent need and constant anxiety for more money had been deeply rooted in Paul's mind, as if dissolving in the air they breathed. The lack of money failed to prevent the couple's vain material pursuit: new furnishings, Paul's tutor and education plan in Eton, luxurious flowers and accessories, the white fur cloak, the endless parties appear as usual despite the madly screaming voices, "There must be more money...Now-w-w...More than ever!" (p. 560). However, Hester the mother, attributed their economic situation to the absence of luck. Therefore, Paul, earning money from the rocking-horse prediction, tried to prove to his mother that he had done a better job than his father in gaining more luck, behaving more as a husband than a son to take care of Hester and concern for the family's economic issues. The imagination of earning a large amount of money by luck without practical endeavors forms the bourgeois fantasy of the era.

Unfortunately, only in a way of fantasy could the wooden horse drive Paul close to her mother, heading for Hester's attention and satisfaction. Then came the heraldically graphic picture,

...[Paul] in his green pajamas, madly surging on his rocking-horse. The blaze of light suddenly lit him up, as he urged the wooden horse, and lit her [Hester] up, as she stood, blonde, in her dress of pale green and crystal... (p. 563)

The boy used up his last breath uttering "Malabar," the name of the winner horse through his prophesy. Unconscious of the surroundings, Paul's blazing eyes turned to "blue stones;" ironically, the mother felt her heart "turned [turn] actually into a stone" (p. 563). Paul's madness of the distorted family relations was released on the rocking-horse. In the end, however, Paul won the game, but Hester lost her son.

The rocking-horse remarks the bourgeois fantasy, which might be the imitation of life, but not true life. The rocking-horse, as one of the delicate toys displayed in the shop-windows is one particular representation of commercialized society. The "expensive and splendid toys" represented by the "shiny modern rocking horse" suggests material possessions that are full of temptations. Paul is the rocking-horse winner, but in fact a loser of life. The only winners in the stories are the real horses, Sansovino, Daffodil, Lancelot, Lively Spark...predicted by Paul to win the race. In contrast with such liveliness, the wooden horse with its "springs" can only be forced into the "mechanical gallop," which is doomed to face the failure. Such an irony reflects the living conditions not merely of the protagonist in the short story, but of a large number of common people submerged in the process of industrial development, Paul's distorted love to his mother being one side of the social diseases.

The objects to which Lawrence applied the elements of fantasy in the three short stories suggest his increasing focus on animality, especially how it shapes humanity. That Lawrence lays emphasis on the lifeless wooden horse instead of the real horses suggests his shifting attention from horse as domesticated animals, and even savages, to a discourse of animality that awakes the restrained humanity against civilization. Lawrence's autobiographical analysis of Paul and Hester's relationship, on the one hand, stands for his own family life and social status; but on the other hand, reflects powerful social conflicts and divisions in the capitalist society, thus showing his intention of seeking remedies for social diseases, in the words of Vincent Pecora, "lay[ing] the cure for all of modernity's ills" (2005, p. 716).

\section{Conclusion}

It is no coincidence that horses occur in many of Lawrence's major works. From a material symbol of Lawrence's nostalgia of the pastoral past, to a life symbol that contains the power of nature, to a discourse of animality that helps shape humanity, D. H. Lawrence is discussing various possibilities of horses. By digging 
into how horses' domesticatedness resembles humans and how their savageness is lost in human beings, Lawrence is exploring and seeking more wholesome humanity, calling for the hidden power in the blood - the animality faraway due to the rapid development of industrialization and commercialization. Fantasy are chosen to juxtapose such binary oppositions as the losing human instincts during the process of civilization as well as the wakening female power in the patriarchal society, thus reaching a balance between the industrialized and primitive power, muscularity and femininity, and a repressive instrumentalism as well as a vibrant organism, just as the real and unreal elements in Lawrence's short stories.

Lawrence had once thought about writing fiction for all people in the world in that "every continent has its own great spirit of place" (1923, p. 17). Despite nationality, every human being bears the blood-consciousness of spiritual freedom. What Lawrence seek is an equilibrium (Note 5) for freedom in between-a new connection between men and men, males and females, men and Nature, providing a way out for modern people who are indulged in the acceleration of mechanic industries.

\section{References}

Bakhtin, M. (1984). Problems of Dostoevsky's Poetics: Theory \& History of Literature (vol. 8, ed. \& trans. by Caryl Emerson). Minneapolis and London: University of Minnesota Press. https://doi.org/10.5749/j.ctt22727z1

Becket, F. (2002). The Complete Critical Guide to D. H. Lawrence. London and NY: Routledge.

Derrida, J. (2002). The Animal That Therefore I Am (More to Follow) (David Wills Trans.). Critical Inquiry, 28(2), 369-418. https://doi.org/10.1086/449046

Edwards, P., Karl, E., \& Elspeth, G. (Eds.). (2012). The Horse as Cultural Icon: The Real and the Symbolic Horse in the Early Modern World. Leiden and Boston: Brill. https://doi.org/10.1163/9789004222427

Freud, S. (2001). Totem and Taboo (James Strachey, trans.). London and NY: Routledge.

Frye, N. (2000). Anatomy of Criticism: Four Essays (15th ed.). Princeton and Oxford: Princeton UP.

Gurko, L. (1972). D. H. Lawrence's Greatest Collection of Short Stories-What Holds It Together. Modern Fiction Studies, 18(2), 173-182.

Hobsbaum, P. (1981). A Reader's Guide to D. H. Lawrence. London: Thames \& Hudson.

Hribal, J. C. (2002). Animals Are Part of the Working Class: Commons, Enclosure, and Resistance in the Atlantic World (Diss.). The University of Toledo.

Jackson, R. (2009). Fantasy: The Literature of Subversion. London and NY: Routledge.

Jenkins, L. M. (2015). The American Lawrence. Gainesville: University Press of Florida.

Lawrence, D. H. (1923a). Kangaroo. NY: Thomas Seltzer.

Lawrence, D. H. (1923b). Studies in Classic American Literature. Cambridge: Cambridge UP.

Lawrence, D. H. (1925). St Mawr, Together with the Princess. London: Martin Secker.

Lawrence, D. H. (1928). The Woman Who Rode Away and Other Stories. Feedbooks. Retrieved from http://www.gutenberg.org

Lawrence, D. H. (1994). The Rocking-horse Winner. In M. Alberto (Ed.), Black Water: The Flamingo Anthology of Fantastic Literature (pp. 550-564). London: Flamingo.

Lawrence, D. H. (2004). Psychoanalysis and the Unconscious and Fantasia of the Unconscious (Bruce Steele, ed.). Cambridge: Cambridge UP.

Lawrence, D. H. (2012). The Horse-dealer's Daughter. In England, My England. Kindle: A Public Domain Book.

Miles, K. (2008). D. H. Lawrence's Short Stories: "The Horse Dealer's Daughter" and "The Rocking Horse Winner." In A. M. Cheryl \& M. David (Eds.), A Companion to the British and Irish Short Story (pp. 183-192). Oxford: Blackwell Publishing Ltd. https://doi.org/10.1002/9781444304770.ch15

Norris, M. (1985). Beasts of the Modern Imagination: Darwin, Nietzsche, Kafka, Ernst, and Lawrence. Baltimore: Johns Hopkins UP.

Pecora, V. (n.d.). D. H. Lawrence. In R. John (Ed.), The Columbia History of the British Novel (pp. 715-739). Beijing \& NY: Foreign Language Teaching and Research Press \& Columbia UP.

Perkins, D. (2007). Romanticism and Animal Rights. NY: Cambridge UP. 
Reidhead, J., \& Marian, J. (Eds.). (2018). The Norton Anthology of English Literature (10th ed., vol. 6). NY \& London: W. W. Norton \& Company.

Tylor, E. B. (1871). Primitive Culture: Researches into the Development of Mythology, Philosophy, Religion, Art, and Custom (vol. 1). London: John Murray, Albemarle Street.

\section{Notes}

Note 1. Critics such as T. S. Eliot and E. M. Forster views unfavorably Lawrence's emotional writing style. In Eliot's letter to Sydney Schiff: "what little I have seen of [D. H.] Lawrence lately makes me think him thoroughly dégringolé [run down]." Ever since F. R. Leavis' overturning Eliot's judgment during the 1950s and 1960s, viewing him as "the essential opposition" regarding the talents of Lawrence, Lawrence's grievance had been redressed and his position in the literary scene settled.

See in Eliot, Valerie, and Hugh Haughto (Eds.). (2011). The Letters of T. S. Eliot (vol. 1, pp. 362-363). Yale University: Faber and Faber. 7 vols.

See in Crick, Brian, and Michael DiSanto (2009). D. H. Lawrence, "An Opportunity and a Test": The Leavis-Eliot Controversy Revisited. The Cambridge Quarterly, 38(2), 130-146. https://doi.org/10.1093/camqtly/bfp006

Note 2. See Peter Edwards, Karl Enenkel and Elspeth Graham (Eds.). (2012). The Horse as Cultural Icon: The Real and the Symbolic Horse in the Early Modern World (p. 27), Leiden and Boston: Brill.

Note 3. According to Hribal, an oblique is a kind of animal-powered machine whereon a horse, a large dog etc. can trot on the outside or inside of the wheel for pumping water, churning milk and so forth for "pumping water, light wood-sawing, churning milk or kneading flour" among which horses also served in transportation, driving carts or coaches for human beings.

See Hribal, Jason C. (2002). Animals Are Part of the Working Class: Commons, Enclosure, and Resistance in the Atlantic World (Diss., p. 66). The University of Toledo.

Note 4. Even though Lawrence himself denies Freud's psychoanalysis, his depiction of mother-son relationship, to a large extent, is influenced by Freud's experiments on Hans. According to Lawrence, "I never read Freud, but I have learned about him since I was in Germany."

See Jennifer Spitzer (Jan 2014). On Not Reading Freud: Amateurism, Expertise, and the "Pristine Unconscious" in D. H. Lawrence. Modernism/Modernity, 21(1), 89-105.

Note 5. The balance between culture and nature as suggested by E. O. Wilson and Stephen Kellert's "biophilia hypothesis."

See Edward Wilson (1984). Biophilia. Cambridge, MA: Harvard UP.

\section{Copyrights}

Copyright for this article is retained by the author, with first publication rights granted to the journal.

This is an open-access article distributed under the terms and conditions of the Creative Commons Attribution license (http://creativecommons.org/licenses/by/4.0/). 